\title{
Erratum to: Échocardiographie transœsophagienne en réanimation : indications et contre-indications en 2017
}

\section{Erratum to: Transesophageal Echocardiography in the Intensive Care Unit: Indications} and Contraindications in 2017 (GFRUP), and the support of the French pediatric pneumology and allergology society (SP2A)

\author{
L. Vallée $\cdot$ K. Chaoui $\cdot$ S. David $\cdot$ B. Riu-Poulenc \\ (C) SRLF et Lavoisier SAS 2017
}

Erratum to : Méd. Intensive Réa DOI 10.1007/s13546-017-1263-2

Une erreur s'est glissée dans le chapitre « Indications ». Il fallait lire : «L'ETO sera retenue chez le patient non échogène pour explorer une instabilité hémodynamique, respiratoire, ou encore un arrêt cardiorespiratoire inexpliqué avec dissociation électromécanique [1]. » 